\title{
HUBUNGAN PAPARAN GAME ONLINE BERUNSUR KEKERASAN TERHADAP KEJADIAN PERILAKU AGRESIF PADA REMAJA
}

\author{
Arentha Ayu Pitakasari ${ }^{1}$, Kandar ${ }^{2}$, Agung Pambudi ${ }^{3}$ \\ ${ }^{1}$ Mahasiswa Program Studi Ilmu keperawatan, STIKES St. Elisabeth Semarang \\ ${ }^{2}$ Perawat RSJD Dr Amino Gondhohutomo Semarang \\ ${ }^{3}$ Dosen Program Studi Ilmu keperawatan, STIKES St. Elisabeth Semarang \\ maskandar31@yahoo.com
}

\begin{abstract}
ABSTRAK
Game online adalah jenis permainan komputer yang memanfaatkan jaringan komputer. Permainan pada game online kebanyakan menampilkan adegan agresif yang secara tanpa sadar perilaku agresif tersebut akan terekam dalam memori alam bawah sadar remaja sehingga sikap agresif pada remaja begitu mudah terbentuk. Penelitian ini bertujuan untuk mengetahui hubungan paparan game online berunsur kekerasan terhadap kejadian perilaku agresif pada remaja di Kelurahan Bulustalan Semarang. Penelitian ini merupakan deskriptif analitik dengan pendekatan cross sectional dan sampel diambil secara total dari populasi yang berjumlah 42 responden. Pengambilan data menggunakan kuesioner dan dianalisis menggunakan uji statistik Chi - Square tabel $2 \times 2$. Uji Chi - Square didapatkan nilai $p=0.733, p>0.005$ disimpulkan tidak ada hubungan paparan game online berunsur kekerasan terhadap kejadian perilaku agresif pada remaja di Kelurahan Bulustalan Semarang. Responden yang sering terpapar game online berunsur kekerasan berjumlah 31 responden $(73,8 \%)$ dan yang jarang berjumlah 11 responden $(26,2 \%)$. Responden yang berperilaku tidak agresif agresif berjumlah 25 responden $(59,5 \%)$ dan responden yang berperilaku agresif berjumlah 17 responden $(40,5 \%)$.
\end{abstract}

Kata kunci: Game online, perilaku agresif

\section{RELATIONSHIP OF ONLINE GAME EXPOSURE TO VIOLENCE TOWARDS AGRESSIVE BEHAVIOR IN ADOLESCENTS}

\begin{abstract}
The online game is a type of computer games that utilize a computer network. Most online games on games featuring aggressive scenes that are unknowingly aggressive behavior will be recorded in the memory of the unconscious teenager so aggressive attitude on adolescent so easily formed. This research goal to know the relationship of exposure to online gaming fraternity violence against the incidence of aggressive behavior in teenagers in Bulustalan village. This research is a descriptive analytic with cross sectional approach and samples taken in total from a population numbering 42 respondents. Data taken by a questionnaire and analyzed using statistical test of Fisher. Fisher obtained value $p=0.733 p>0,005$ concluded there is no relationship of exposure to online gaming fraternity violence against the incidence of aggressive behavior in teenagers in Bulustalan village. Respondents who were often exposed to online gaming fraternity violence amounted to $31(73,8 \%)$ and respondents who seldom numbered 11 respondents (26.2\%). Respondents who don't behave aggressively aggressive totaled 25 respondents $(59,5 \%)$ and respondents who behave aggressively totaled 17 respondents (40.5\%).
\end{abstract}

Keywords: online game, aggressive behavior

\section{PENDAHULUAN}

Tingkah laku agresif yang dilakukan anak usia sekolah akhir-akhir ini menjadi topik menarik untuk dibahas. Perkelahian antar pelajar saat ini bukan menjadi hal baru lagi. Perkembangan teknologi yang semakin pesat dewasa ini memiliki andil besar dalam mempengaruhi sikap agresif anak - anak usia sekolah.
Faktor media online sangat berpengaruh pada individu untuk melakukan tindakan kekerasan karena dapat dengan mudah diakses. Salah satu media online yang saat ini sedang digemari remaja adalah game online (Permana, 2012). Game online itu sendiri bisa berkembang sangat pesat di Indonesia karena didukung dengan perkembangan internet. Hingga akhir tahun 2014, jumlah pengguna internet di seluruh dunia 
diprediksi mencapai 3 miliar. Dua pertiganya berasal dari penduduk di negara-negara berkembang. Jumlah 3 miliar tersebut sudah sama dengan 40 persen populasi penduduk bumi (Nistanto, 2014). Pertumbuhan pengguna internet di Indonesia juga semakin pesat setiap tahunnya. Jumlah pengguna internet tumbuh signifikan hingga 22 persen dari 62 juta di tahun 2012 menjadi 74,57 juta di tahun 2013. Menurut lembaga riset MarkPlus Insight, angka jumlah pengguna internet di Indonesia akan menembus seratus juta jiwa di tahun 2015. Data dari Kementerian Komunikasi dan Informatika (Kemkominfo) pengguna internet di Indonesia hingga saat ini telah mencapai 82 juta orang. Dari jumlah pengguna internet tersebut, 80 persen di antaranya adalah remaja berusia 15-19 tahun (Bintang, 2014). Mereka menggunakan internet untuk mengakses media sosial seperti facebook, twitter dan youtube. Banyak juga dari mereka yang menggunakan internet untuk bermain game online.

Saat ini terdapat kurang lebih 700 juta pemain game online di dunia. Negara Turki menjadi negara dengan persentase pemain game online terbesar di dunia atau sekitar 70 persen dari pengguna online internet (Maulana, 2013). Di Indonesia jumlah pemain game terus menerus bertambah, bahkan saat ini Indonesia mengalami pertumbuhan pemain game hingga 33 persen setiap tahunnya. Tahun 2012 di Indonesia terdapat tiga puluh juta pengguna game online dengan rata-rata umur pengguna antara 17 tahun hingga 40 tahun.

Permainan pada game online kebanyakan menampilkan perkelahian brutal, berdarah-darah, sadis, adegan penyiksaan, pembunuhan dan lainlain. Jika permainan tersebut digemari dan dinikmati secara berulang-ulang, secara tanpa sadar perilaku agresif tersebut akan terekam dalam memori alam bawah sadar remaja. Akibatnya, remaja menjadi terbiasa menyaksikan adegan kekerasan, sehingga sikap agresif pada remaja begitu mudah terbentuk. Perilaku agresif yang sering muncul di media elektronik sering dihubung - hubungkan dengan perilaku agresif di dunia nyata. Hal itu disebutkan dalam penelitian yang dilakukan oleh Michelle L. Yebarra pada tahun 2009, bahwa perilaku agresif di dalam media berhubungan dengan perilaku agresif yang serius dikalangan remaja. ${ }^{1}$ Sebagai contoh kasus gara-gara game online, seorang Anak Baru Gede asal Vietnam secara sadis tega membunuh seorang nenek. Hal ini dilakukannya karena anak ingin merampok uang si nenek hanya untuk bermain game online. Tahun 2010 lalu di Alabama, Amerika Serikat terdapat satu kasus yang menyebutkan bahwa seorang remaja bermain game First Person Shooter selama berbulan-bulan dan akhirnya dia terbukti bersalah karena telah membunuh tiga orang yang dua di antaranya adalah polisi. Pelaku membunuh tiga orang tersebut karena terinspirasi oleh game berjudul Grand Theft Auto. Di daerah Tangerang, ada kasus perampokan yang terinspirasi game online FPS Point Blank. Dalam game itu diatur pemain akan mendapatkan point jika melakukan serangkaian kekerasan mulai memukul, merampok, menabrakkan mobil dan sebagainya (NR, 2013).

Berdasarkan data Polri pada tahun 2008 ada 3.380 anak dan tahun 2009 ada 4.213 anak bermasalah dengan hukum. Data dari Kementerian Hukum dan HAM, Ditjen Pemasyarakatan menyebutkan jumlah narapidana anak remaja meningkat dari 5.360 pada tahun 2008 menjadi 6.308 pada tahun 2010 (Gumelar, 2012). Hasil survey yang dilakukan Daniel Yudha Kumoro pada tahun 2008 terhadap 25 remaja di salah satu kecamatan di wilayah Kota Sidoarjo menunjukkan sebanyak 13 pelajar pernah berkelahi di sekolah dan merusak barang - barang yang ada bila sedang marah. Hasil survey diketahui bahwa dari 13 pelajar tersebut, 11 diantaranya senang bermain video game jenis kekerasan. ${ }^{1}$ Berdasarkan penelitian yang dilakukan Melani pada tahun 2009 yang berjudul "Studi Kasus Tentang Pengaruh Game Online Terhadap Agresivitas Remaja di Surabaya" beberapa tindakan yang terlihat agresif yang ditimbulkan remaja pria untuk meluapkan kekesalan atau rasa frustasi saat bermain game antara lain agresivitas untuk berkumpul bersama teman-teman untuk bermain game, agresif untuk bermain permainan yang dimainkan dalam game online, keinginan bermain game dengan teriakan, umpatan, maupun mengganggu pemain lain, bermain game dengan lebih agresif, seperti menghentakkan keyboard, menghentakkan mouse, memukul dan menendang peralatan komputer, mencari masalah pada media chating, memukul meja, memukul property warnet, menyebabkan timbulnya keinginan untuk merokok, tindakan mengumpat, yang dimaksud tindakan mengumpat disini adalah ucapan yang ditujukan kepada orang lain dengan tujuan memberi peringatan, meluapkan amarah, maupun tindakan agresif yang cenderung mengajak untuk bermusuhan (misuh) seperti: "taaaaeekkk", "cooookkk", "gathel", "asu", "jangkriiikk", "goblok", "keparaaaaatttt", tindakan membalas chating dengan kata-kata yang mengumpat ataupun dialek daerah yang kasar 
dengan tujuan mengejek, ataupun membalas ejekan dari teman yang dirasa menyinggung (Ramadhani, 2015).

Hasil penelitian Jansz menyatakan bahwa pengguna game online kebanyakan adalah para remaja. Hal ini sejalan dengan Bakker yang menyatakan bahwa para pecandu game rata - rata 13 - 30 tahun dengan presentase 80 persen berusia 13 - 25 tahun. Didukung pula oleh survey yang dilakukan oleh Media Analysis Laboratory menggungkapkan bahwa pengguna game online terbanyak adalah remaja yang berumur 12-15 tahun atau remaja awal yang setara dengan siswa Sekolah Menengah Pertama (SMP) (Permana, 2015).

Data dari Kelurahan Bulustalan, sekitar bulan Pebruari 2015 salah seorang warganya, Anak A. yang masih berusia 14 tahun kedapatan mencuri handphone milik temannya. Anak A. ini diketahui sering bermain game online di warnet $\mathbf{J}$ yang tak jauh dari rumahnya. Kasus ini ditangani pihak kepolisian tetapi karena Anak A. masih di bawah umur maka tidak dipidanakan. Observasi yang dilakukan di wilayah Kelurahan Bulustalan, peneliti mendapati ada 3 warnet game online. Pengunjung warnet tersebut juga mayoritas anak - anak usia sekolah. Penjaga di warnet $\mathbf{J}$ mengatakan bahwa game yang paling sering dimainkan di warnet tersebut adalah Point Blank yang merupakan game tembak tembakan. Tiga dari empat orang ibu yang peneliti wawancara mengatakan anak mereka yang masih duduk di Sekolah Menengah Pertama hampir setiap hari bermain game online dari pulang sekolah sekitar jam 13.00 sampai jam 17.00, pulang untuk mandi lalu kembali bermain game online sampai terkadang lupa makan. Ibu lainnya menambahkan, anaknya sering mengucapkan kata - kata kasar bila sedang emosi. Berdasarkan fenomena di atas peneliti tertarik untuk melakukan penelitian tentang hubungan paparan game online berunsur kekerasan terhadap kejadian perilaku agresif pada remaja di Kelurahan Bulustalan Semarang.

\section{METODE}

Jenis penelitian ini adalah deskriptif analitik dengan pendekatan cross sectional. Sampel dalam penelitian ini adalah orang tua yang memiliki anak remaja laki - laki berusia 13 18 tahun dan memainkan game online berunsur kekerasan di kelurahan Bulustalan Semarang yang berjumlah 42 orang.

\section{HASIL}

Pengambilan data dilakukan di warnet Just Alfa pada 10 - 14 Juni 2015 kepada 42 responden remaja yang memainkan game online berunsur kekerasan dengan cara mengisi kuesioner. Di wilayah Kelurahan Bulustalan terdapat 3 warnet namun yang menyediakan fasilitas khusus game online hanya warnet Just Alfa. Warnet tersebut memiliki 16 bilik game online. Pengunjungnya adalah remaja yang rata - rata bermain selama 3-4 jam sehari. Remaja yang memainkan game online berunsur kekerasan diberikan kuesioner penelitian dan selanjutnya untuk kuesioner perilaku agresif diberikan kepada 42 orang tua/wali dari remaja yang memainkan game online tersebut sesuai kriteria inklusi dan eksklusi. Tempat Penelitian di wilayah Kelurahan Bulustalan dan dilakukan pada 10 - 18 Juni 2015.

\section{Analisa Univariat}

Karakteristik responden berdasarkan usia menggambarkan karakteristik usia responden yang paling banyak adalah usia 13 dan 14 tahun yaitu sebanyak 11 responden $(26.2 \%)$. Usia dengan responden paling sedikit adalah usia 17 tahun yang berjumlah 3 responden $(7,1 \%)$. Karakteristik Responden berdasarkan pendidikan terakhir menunjukkan karakteristik responden paling banyak pendidikan terakhirnya adalah SD berjumlah 28 orang $(66.7 \%)$ dan yang paling sedikit pendidikan terakhirnya SMA berjumlah 3 orang $(7.1 \%)$.

Karakteristik Responden berdasarkan paparan game online menunjukkan karakteristik responden yang sering terpapar game online berunsur kekerasan lebih banyak yaitu berjumlah 31 orang $(73.8 \%)$ dibandingkan dengan yang jarang terpapar berjumlah 11 orang (26.2\%). Karakteristik responden berdasarkan kejadian perilaku agresif menunjukkan karakteristik responden yang berperilaku tidak agresif lebih banyak dibandingkan dengan responden yang berperilaku agresif. Responden yang berperilaku 
tidak agresif berjumlah 25 orang $(59,5 \%)$ sedangkan yang berperilaku agresif berjumlah 17 orang $(40,5 \%)$.

Karakteristik responden orang tua/wali berdasarkan usia menunjukkan kelompok usia orang tua/wali yang paling banyak adalah kelompok usia 41-50 tahun sebanyak 19 orang (45.2\%) dan yang paling sedikit adalah kelompok usia >60 tahun sebanyak 1 orang $(2.4 \%)$. Karakteristik paparan game online berdasarkan usia remaja menunjukkan kelompok umur yang paling banyak jarang terpapar game online adalah kelompok usia 15 tahun sebanyak 4 orang $(9.5 \%)$ dan yang paling sedikit kelompok usia 17 tahun yaitu tidak ada. Responden yang paling banyak sering terpapar adalah kelompok usia 13 tahun sebanyak 9 orang (21.4\%) dan yang palin sedikit kelompok usia 16 dan 17 tahun sebanyak 3 orang $(7.1 \%)$

Karakteristik kejadian perilaku agresif berdasarkan usia remaja menunjukkan yang paling banyak berperilaku agresif adalah kelompok usia 14 tahun sebanyak 6 orang (14.3\%) dan yang paling sedikit adalah kelompok usia 17 tahun sebanyak 1 orang (2.4\%). Kelompok usia yang paling banyak tidak agresif adalah umur 13 sebanyak 8 orang (19\%) dan yang paling sedikit berperilaku tidak agresif adalah kelompok usia 16 tahun sebanyak 1 orang $(2.4 \%)$.

\section{PEMBAHASAN}

\section{Paparan Game Online}

Faktor media online sangat berpengaruh pada individu untuk melakukan tindakan kekerasan karena dapat dengan mudah diakses. Salah satu media online yang saat ini sedang digemari remaja adalah game online. ${ }^{1}$ Hasil penelitian menunjukkan responden yang sering terpapar game online berunsur kekerasan lebih banyak yaitu berjumlah 31 orang $(73.8 \%)$ dibandingkan dengan yang jarang terpapar berjumlah 11 orang $(26.2 \%)$.

Kelompok usia yang paling banyak jarang terpapar game online adalah kelompok usia 15 tahun sebanyak 4 orang $(9.5 \%)$ dan yang paling sedikit kelompok usia 17 tahun yaitu tidak ada. Responden yang paling banyak sering terpapar adalah kelompok usia 13 tahun sebanyak 9 orang $(21.4 \%)$ dan yang paling sedikit kelompok usia 16 dan 17 tahun sebanyak 3 orang (7.1\%). Rata - rata responden menghabiskan waktu 3-4 jam sehari untuk bermain game online tanpa istirahat.

\section{Perilaku Agresif}

Agresif merupakan tingkah laku menyerang baik secara fisik maupun verbal, atau baru berupa ancaman yang disebabkan adanya permusuhan. ${ }^{14}$ Perilaku agresif yang sering muncul di media elektronik sering dihubung - hubungkan dengan perilaku agresif di dunia nyata. ${ }^{1}$

Hasil penelitian didapatkan responden yang berperilaku agresif sebanyak 17 orang (40.5\%). Saat pengambilan data, salah seorang ibu dari remaja mengatakan anaknya berbicara dengan tidak sopan setiap harinya. Ibu tersebut juga mengatakan anaknya menghabiskan waktu di luar rumah untuk bermain game setiap harinya, pulang hanya untuk makan dan mandi. Tidak jarang anaknya tidak pulang dan tidur di warnet. Hasil penelitian remaja yang tidak berperilaku agresif sebanyak 25 orang (59.5\%). Responden yang tidak agresif memang lebih banyak dibandingkan dengan responden yang berperilaku agresif, namun ini tidak bisa dianggap remeh karena sekitar $40 \%$ dari jumlah responden berperilaku agresif.

Hasil penelitian menunjukkan responden yang paling banyak berperilaku agresif adalah kelompok umur 14 tahun sebanyak 6 orang (14.3\%). Umur 14 tahun masuk ke dalam masa remaja awal yang mempunyai ciri diantaranya ingin dekat dengan teman sebaya, ingin bebas dan mencoba hal - hal baru. ${ }^{12} \mathrm{Hal}$ baru yang dicoba diantaranya adalah game online yang banyak mengandung unsur kekerasan. Jika permainan tersebut digemari dan dinikmati secara berulang-ulang, secara tanpa sadar perilaku agresif tersebut akan terekam dalam memori alam bawah sadar remaja. Akibatnya, remaja menjadi terbiasa menyaksikan adegan kekerasan, sehingga sikap agresif pada remaja begitu mudah terbentuk.

Hasil penelitian juga menunjukkan yang paling sedikit berperilaku agresif adalah kelompok umur 17 tahun sebanyak 1 orang 
(2.4\%). Remaja usia 17 tahun masuk ke dalam masa remaja tengah yang sudah mulai mengembangkan kemampuan berpikir. Remaja tengah sudah mampu berpikir tentang dampak positif maupun negatif dari perbuat yang dilakukan sehingga mereka sudah mampu mengendalikan diri agar tidak terkena dampak negatif dari game online berunsur kekerasan.

Kelompok umur yang paling banyak berperilaku tidak agresif adalah umur 13 tahun sebanyak 8 orang (19\%). Remaja umur 13 tahun masuk ke dalam remaja awal yang cenderung ingin bebas dan tidak suka diatur atur. ${ }^{12}$ Remaja yang paling sedikit berperilaku tidak agresif adalah kelompok umur 16 tahun sebanyak 1 orang (2.4\%). Perilaku remaja dipengaruhi juga oleh faktor pola asuh orang tua. Penerapan pola demokratis berdampak positif terhadap perkembangan remaja, karena senantiasa dilatih untuk mengambil keputusan dan siap menerima segala konsekuensi dari keputusan yang diambil. Sementara orang tua memberikan kontrol dan bimbingan manakala remaja melakukan hal-hal negatif yang dapat merusak kepribadian. ${ }^{33}$ Pola asuh permisif di mana orang tua cenderung memberikan banyak kebebasan kepada anaknya dan kurang memberikan kontrol sehingga remaja tidak punya kontrol diri yang baik. ${ }^{33}$ Pola asuh ini dapat menyebabkan remaja mudah berperilaku agresif karena pengaruh lingkungan dan tidak ada kontrol dari orang tua.

\section{Hubungan Paparan Game Online Berunsur Kekerasan Terhadap Kejadian Perilaku Agresif}

Analisis hasil penelitian didapatkan usia responden remaja yang paling banyak adalah usia 13 dan 14 tahun yaitu sebanyak 11 responden $(26.2 \%)$. Usia dengan responden paling sedikit adalah usia 17 tahun yang berjumlah 3 responden (7.1\%). Responden orang tua kelompok usia yang paling banyak adalah kelompok usia 41-50 tahun sebanyak 19 orang $(45.2 \%)$ dan yang paling sedikit adalah kelompok usia $>60$ tahun sebanyak 1 orang $(2.4 \%)$.

Jumlah responden yang pendidikan terakhirnya SD paling banyak yaitu berjumlah 28 orang $(66.7 \%)$ dan yang paling sedikit pendidikan terakhirnya SMA berjumlah 3 orang (7.1\%).
Peran sekolah atau pendidikan jauh lebih luas yaitu pendidikan berperan sebagai pembentukan sikap-sikap dan kebiasaan yang wajar bagi individu. Selain itu sekolah juga memegang peran penting dalam pendidikan karena pengaruhnya besar sekali terhadap jiwa. Dapat disimpulkan jika semakin tinggi pendidikan semakin baik pembentukan sikap sehingga remaja dapat membedakan mana yang baik dan mana yang buruk untuk dirinya. Saat penelitian peneliti menemukan 3 orang responden yang mengaku pernah menjalani hidup sebagai gelandangan dengan motif ikut dengan teman. Sepuluh dari 42 orang responden mengalami putus sekolah. Mereka mendapatkan uang untuk main game online dari orang tua, ada juga 4 remaja yang mengaku berprofesi sebagai pengamen. Uang yang dihasilkan dari mengamen digunakan untuk membeli rokok dan bermain game online.

Analisis Chi-Square dengan table $2 \times 2$ tidak memenuhi syarat uji maka dilanjutkan dengan uji alternatif Fisher didapatkan hasil $p$ value $=0.733$, $p>0.05$ memiliki arti $\mathrm{H}_{0}$ diterima, disimpulkan tidak ada hubungan paparan game online berunsur kekerasan terhadap kejadian perilaku agresif pada remaja di Kelurahan Bulustalan Semarang. Hasil ini berbeda dengan penelitian yang dilakukan Luqman Syarief (2013) dengan judul Hubungan Kebiasaan Menonton Tayangan Kekerasan Di Televisi Dengan Perilaku Agresif Pada Anak Pra Sekolah Di TK Islam Terpadu Al Akhyar Kabupaten Kudus. Hasil uji statistik didapatkan p value $(0.000)<(0.05)$ yang menunjukkan ada hubungan kebiasaan menonton tanyangan kekerasan di televisi dengan perilaku agresif pada anak pra sekolah di TK islam terpadu Al Akhyar Kabupaten Kudus.

Hasil penelitian yang berbeda dapat dipengaruhi oleh usia responden, penelitian tersebut mengambil responden anak usia pra sekolah. Anak - anak cenderung menirukan setiap kejadian dan tingkah laku dari aktor yang mereka lihat tersebut sehingga dapat membuat anak untuk melakukan kekerasan yang mungkin secara tidak sengaja dilakukan dan itu membuat pribadi anak menjadi pribadi yang keras. ${ }^{11}$ Penelitian ini mengambil responden anak usia remaja yang mempunyai kemampuan berpikir lebih dibandingkan anak usia pra sekolah. Hasil penelitian ini memang menunjukkan tidak ada hubungan paparan game online terhadap perilaku agresif pada remaja, namun pada saat pengambilan data peneliti melihat sendiri responden banyak berperilaku agresif misalnya saja membanting mouse, bahkan salah satu 
responden sempat melecehkan peneliti dengan kata-kata yang tidak senonoh. Saat pengisian kuesioner oleh orang tua didapatkan data tidak semua orang tua mengetahui perilaku anaknya di luar rumah, karena mereka tidak selalu bersama anak mereka. Di rumah remaja berperilaku baik namun ketika di luar rumah atau saat bersama teman - temannya mereka berperilaku agresif akibat pengaruh lingkungan sekitar. Hal ini didukung dari hasil penelitian ada $40.5 \%$ remaja yang berperilaku agresif.

\section{SIMPULAN DAN SARAN}

\section{Simpulan}

1. Hasil responden remaja yang "sering" terpapar game online berunsur kekerasan lebih banyak yaitu berjumlah 31 responden ( $73,8 \%$ ) daripada yang "jarang" terpapar game online berunsur kekerasan yang berjumlah 11 responden $(26,2 \%)$.

2. Hasil penelitian dari responden orang tua, remaja yang tidak berperilaku agresif lebih banyak yaitu berjumlah 25 responden $(59,5 \%)$ daripada responden yang berperilaku agresif berjumlah 17 responden $(40,5 \%)$.

3. Hasil analisis uji Fisher didapatkan nilai $p$ $=0.733$, hasil nilai $p>0.05$ yang berarti $\mathrm{H}_{0}$ diterima sehingga dapat disimpulkan tidak ada hubungan paparan game online berunsur kekerasan terhadap kejadian perilaku agresif di Kelurahan Bulustalan Semarang.

\section{Saran}

1. Bagi Peneliti Selanjutnya

Perlu dilakukan penelitian selanjutnya dengan variabel bebas lingkungan, pendidikan dan pola asuh dengan variabel terikat perilaku agresif.

2. Bagi Orang Tua

Para orang tua lebih memperhatikan game yang dimainkan anak dan menjelaskan dampak negatif game terhadap anak. Sebaiknya orang tua membatasi waktu bermain game anak, misalnya saja memberikan waktu anak bermain game online pada saat weekend atau mungkin seminggu sekali.

\section{DAFTAR PUSTAKA}

Permana, Dwi Iman. (2012). Profil Kecenderungan Perilaku Agresif Remaja yang Bermain Online Game. [homepage on the Internet]. No date [cited 2015 Feb 9]. Available from : http://aresearch.upi.edu/operator/upload/s bk 070 3953 chapter1.pdf

Nistanto, Reska K.(2014). Pengguna Internet Capai 3 Miliar [homepage on the Internet]. c2014 [updated 2014 May 08; cited 2015 Mar 5]. Available from : http://tekno.kompas.com/read/2014/05/08/1 114312/tahun.ini.pengguna.internet.capai.3. $\underline{\text { miliar }}$

Bintang. Kemkominfo. (2014). Pengguna Internet di Indonesia Capai 82 Juta [homepage on the Internet]. c2014 [update 2014 May 8; cited 2015 Mar 5]. Available from : http://kominfo.go.id/index.php/content/deta il/3980/Kemkominfo\%3A+Pengguna+Inter net+di+Indonesia+Capai+82+Juta/0/berita satker\#.VPhUwnyUd3c

Maulana, Adhi. (2013). 7 Fakta Dunia Game di Penghujung Tahun 2013 [homepage on the Internet]. c2013 [update 2013 Des 11; cited 2015 Mar 5]. Available from : http://tekno.liputan6.com/read/771267/7fakta-dunia-game-di-penghujung-tahun$\underline{2013}$

NR, Iman. (2013). Awas Game Online Kekerasan Picu Kejahatan Anak [homepage on the Internet]. c2013 [update 2013 Aug 28; cited 2015 Feb 18]. Available from http://mediabanten.com/content/awasgame-online-kekerasan-picu-kejahatan$\underline{\text { anak }}$

Gumelar, Linda Amalia Sari. (2015). Angka Kasus Anak Bermas ${ }^{-1}$ Hukum Meningkat [homepage on the Ir tt]. c2012 [update 2012 Apr 27; cited _.... Mar 5]. Available from

http://www.politikindonesia.com/index.php ?k=politik\&i=33702-Angka-Kasus-Anak-

Bermasalah-Hukum,-Meningkat

Ramadhani,Ardi. (2015). Hubungan Motif Bermain Game Online Dengan Perilaku Agresivitas Remaja Awal (Studi Kasus di Warnet Zerowings, Kandela, dan Mutant di Samarinda) [homepage on the Internet]. No date [cited $2015 \mathrm{Feb}$ 9]. Available from : http://ejournal.ilkom.fisipunmul.ac.id/site/wpcontent/uploads/2013/0 
4/eJournal Ardi\%20Ramadhani\%20rev\%2 0(04-13-13-02-17-37).pdf

Rollings, Andrew; Ernest Adams. (2006). Dasar dasar desain game. Prentice Hall.2006.

N.K., Adaman. (2005). Desain sejarah permainan game online. McGraw-Hill.

Smart, Aqila. (2010). Cara Cerdas Mengatasi Anak Kecanduan Game. Jogjakarta : A plus books.

Sujatmoko, Arif. (2012). Video Game mengubah Aktivitas Otak [homepage on the Internet]. c2012 [update 2012 Apr 27; cited 2015 Mar 5]. Available from : http://nationalgeographic.co.id/berita/2012/ 04/video-game-mengubah-aktivitas-otak

Surbakti. (2008). Awas Tayangan Televisi Tayangan Misteri dan Kekerasan Mengancam Anak Anda. Jakarta : PT Elex Media Komputindo Kelompok Gramedia.

Jackman, Ann. (2005). How to Negotiate. Jakarta : Erlangga.

Nisfiannoor, M. (2005). Perbandingan Perilaku Agresif Antara Remaja Yang Berasal Dari Keluarga Bercerai Dengan Keluarga Utuh. Journal Psikologi Vol. 3 No. 1 [serial online]. 2005 [cited 2015 Mar 14]. Available from http://download.portalgaruda.org/article.ph $\mathrm{p}$ ?article $=62929 \& \mathrm{val}=4564$

Videbeck. Sheila L. (2008). Buku Ajar Keperawatan Jiwa. Jakarta : Buku Kedokteran EGC.

Efendi, Ferry - Makhfudli. (2009). Keperawatan Kesehatan Komunitas Teori dan Praktik dalam Keperawatan. Jakarta : Salemba Medika.

Wasis. (2008). Pedoman Riset Praktis untuk Profesi Perawat. Jakarta : Buku Kedokteran EGC.
Nursalam. (20140. Metodologi Penelitian Ilmu Keperawatan. Jakarta : Salemba Medika.

Sastroasmoro, sudigdo. (2011). Dasar - Dasar Metodologi Penelitian Klinis Edisi ke-4. Jakarta : Sagung Seto

Hidayat, Aziz Alimul. (2007). Metode Penelitian Keperawatan dan Teknik Analisis Data. Jakarta : Salemba Medika.

Susilo, HW. (2012). Statistika \& Aplikasi Untuk Penelitian Ilmu Kesehatan. Jakarta : Trans Info Medika.

Swarjana. I Ketut. (2012). Metodelogi Penelitian Kesehatan. Yogyakarta : Andi Offset.

Hidayat, Aziz Alimul. (2014). Metode Penelitian Kebidanan dan Teknik Analisis Data. Jakarta : Salemba Medika.

Riyanto, Agus. (2013). Statistik Deskriptif Untuk Kesehatan. Yogyakarta : Nuha Medika.

Setiadi. (2013). Konsep dan Praktik Penulisan Riset Keperawatan. Edisi 2. Yogyakarta: Graha Ilmu.

Notoadmodjo. (2013). Metodologi Penelitian Kesehatan. Jakarta : Salemba Medika.

Budiharto. (2008). Metodologi Penelitian Kesehatan dengan Contoh Bidang Ilmu Kesehatan Gigi. Jakarta : EGC.

Dahlan, M. Sopiyudin. (2011). Statistik Untuk kedokteran Dan Kesehatan. Jakarta: Salemba Medika.

Hidayat, AA. (2009). Metode Penelitian Keperawatan dan Teknik Analisis Data. Jakarta: Salemba Medika. 